\title{
Short-term Memory and Language Processing: Further Evidence for the Existence of Separate Phonological and Semantic Short-term Memory Components
}

S. Majerus, M. Van der Linden and C. Renard

\section{OpenEdition}

\section{Journals}

Electronic version

URL: http://journals.openedition.org/cpl/175

DOI: $10.4000 / \mathrm{cpl} .175$

ISSN: $1379-6100$

\section{Publisher}

Centre PsyCLÉ

Printed version

Date of publication: 1 April 2001

\section{Electronic reference}

S. Majerus, M. Van der Linden and C. Renard, « Short-term Memory and Language Processing: Further Evidence for the Existence of Separate Phonological and Semantic Short-term Memory

Components », Current psychology letters [Online], 2001/1, 4| 2001, Online since 05 September 2003, connection on 08 September 2020. URL : http://journals.openedition.org/cpl/175 ; DOI : https:// doi.org/10.4000/cpl.175

This text was automatically generated on 8 September 2020

(c) All rights reserved 
Short-term Memory and Language Processing: Further Evidence for the Existence of Separate Phonological and Semantic Short-term Memory Components

S. Majerus, M. Van der Linden and C. Renard 